\title{
銀-1,10-フェナントロリン-過塩素酸三元錯体の生成反応を 利用する過塩素酸イオンの電導度滴定
}

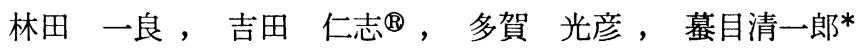

(1979 年 11 月 5 日受理)

\begin{abstract}
過塩素酸イオンは銀 (I) 及び 1,10-フェナントロリン（以下 phen と略記）の存在下で難溶性三元錯 体, $\mathrm{Ag}(\mathrm{phen})_{2} \mathrm{ClO}_{4}$ を形成する. この三元錯体の生成反応を利用する過塩素酸イオンの簡便な電導度 滴定法について検討した. (6〜34) $\mathrm{mg}$ の過塩素酸イオンを含む試料溶液に酢酸塩䌅衝溶液を加えて $\mathrm{pH}$ を 5.0 とした後, $\mathrm{Ag}(\mathrm{phen})_{2}{ }^{+}$錯体標準溶液（40\%エタノール溶液）で滴定する. 本法によれば, $0.2 \%$ 以下の相対誤差と， $0.9 \%$ 以下の相対標準偏差で過塩素酸イオンを簡便に定量することができ た．共存イオンの影響についても詳しく検討した。本法を過塩素酸アンモニウムの純度検定に応用した ところ，従来法と良く一致した結果が得られた。生成する三元錯体の見掛けの溶解度積 $\left(\log K_{\mathrm{sp}}{ }^{\prime}\right)$ は -24.25 であり, この值から反応熱が $36.7 \mathrm{kcal}$ と算出された。
\end{abstract}

\section{1 緒言}

過塩素酸イオンの容量分析法としては幾つかあるが, 酸化還元滴定法が広く用いられている1) 6)。この方法 は，過塩素酸イオンを種々の還元剤を用いて塩化物イオ ンとし，この塩化物イオンを定量するか11 〜4)，あるい は過剩の還元剤を適当な酸化剤を用いて逆滴定する方 法5)6) など主として間接的な滴定法である。そのため定 量条件の設定が困難であり，又操作が煩雑となるなど種 種の難点がある.

直接滴定法に関する報告も見受けられるが7) 9)，塩化 テトラフェニルアルソニウムや塩化テトラフェニルホス ホニウムによる方法以外の検討は少ない.

一方，1，10-フェナントロリン(phen)が重金属イオン 及び種々の陰イオンと反応して生成する三元錯体は，そ れら陰イオンの光度定量や原子吸光法による定量に広く 利用されているが10)，滴定法に応用された報告はほとん ど見当たらない，著者らはこれまで phen が関与する 三元錯体の生成反応を利用したカドミウム(II) の電導 度滴定 ${ }^{11)}$ ，重量分析 ${ }^{12)}$ 及び水銀 $(\mathrm{II})$-銀 (I) -カドミウム （II）の同時定量 ${ }^{13)}$ について検討してきた. 本報は，過 塩素酸イオンが銀(I) 及び phen と反応して難溶性の三 元錯体, $\mathrm{Ag}(\mathrm{phen})_{2} \mathrm{ClO}_{4}$, を形成することに着目し, 過 塩素酸イオンの簡便な直接定量法の確立を目的として電

* 北海道大学理学部化学教室 : 北海道札幌市北区北 10 条西 8 丁目
導度滴定法により検討したものである.

この三元錯体の生成反応を利用する過塩素酸イオンの 滴定法としては，(1) 銀 (I) 共存下に phen で滴定する 方法, (2) phen 共存下に銀 (I) で滴定する方法, (3) $\mathrm{Ag}$ (phen) ${ }_{2}{ }^{+}$錯体で滴定する方法が考えられる. (1), (2) の方法では, あらかじめ共存させる銀 (I) あるいは phen が過塩素酸イオンに対して等モル量, 及び 2 倍モ ル量をそれぞれ正確に添加する必要があるなど操作上の 難点があった. 他方，(3)の $\mathrm{Ag}(\mathrm{phen})_{2}{ }^{+}$錯体で滴定 する方法はそれらに比べ，定量操作が非常に簡便となる こと, 終点検知が容易であること, 比較的低濃度試料が 定量可能であること, 試薬が安価であることなど幾つか の利点を有する方法であることを知った.

なお，三元錯体の見掛けの溶解度積を求めるとともに 反応熱についても検討した.

以下，それらの結果について報告する。

\section{2 試薬及び装置}

\section{1 試 薬}

$0.1 \mathrm{M} \mathrm{Ag}(\mathrm{phen}){ }_{2}{ }^{+}$錯体標準溶液(40\%エタノール 溶液) : 硫酸デシケーター中で乾燥させた 酶酸銀（和光 純薬製) $17 \mathrm{~g}$ を採り，これに phen(和光純薬製特級) を銀(I) に対してモル比で 2.0 となるように添加する. これを $400 \mathrm{ml}$ エタノールに溶解し水で 11 とする. その正確な濃度は次のようにして求めた。すなわち,

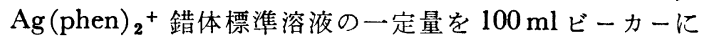
採り, 黄色の呈色が消失するまで濃アンモニフ水を添加 
する．水を加えて全量を $100 \mathrm{ml}$ とした後，硫化ナトリ ウム 標潐溶液を用いる電導度滴定により銀 $(\mathrm{I})$ 量の測 定から求めた。なお，硫化ナトリウム標準溶液は，硫 化ナトリウム九水和物（和光純薬製特級）から調製し， Bethge'4) の方法に従って標定した.

この $\mathrm{Ag}(\mathrm{phen})_{2}{ }^{+}$錯体標準溶液の力価は 2 週間は変 動なく安定に使用することができた.

$0.01 \mathrm{M}$ 過塩素酸イオン標準溶液: 過塩素酸カリウム （和光純薬製特級）を用い, 大久保ら ${ }^{15)}$ の方法に従って 調製した。

酢酸塩綏衝溶液：既報11) と同様に調製した。

その他使用した試薬はすべて市販特級品を用いた。

\section{2 装}

電導度滴定には既報 ${ }^{11)}$ と同じものを，銀 (I) 濃度の測 定には日立 208 型原子吸光分析装置を用いた。

\section{3 定量操作}

(6〜34) $\mathrm{mg}$ の過塩素酸イオンを含む試料溶液を 100 $\mathrm{ml}$ ビーカーに採り, 酢酸塩緩衝溶液（pH 5.0）をそ の濃度が最終 $0.06 \mathrm{M}$ となるように加えた後全量を水で 約 $75 \mathrm{ml}$ とする. 共存する金属イオンは，既報11) と同 様にあらかじめ phen で滴定してマスキングしておく. 全量を水で $100 \mathrm{ml}$ としてから $0.20 \mathrm{ml} / \mathrm{min}$ の速度で $\mathrm{Ag}$ (phen $)_{2}{ }^{+}$錯体標準溶液（40\%エタノール溶液）を 滴加し電導度変化を記録する. 滴定曲線上の屈折点から 過塩素酸イオン量を求める.

\section{4 定量条件の検討と結果}

\section{1 滴定曲線}

Fig. 1 は, $22.65 \mathrm{mg}$ の過塩素酸イオンを採り，3の 定量操作に従って滴定した際の滴定曲線である. 終点は 直線 $\mathrm{AB}$ と直線 $\mathrm{CD}$ の交点として簡単明りょうに検知 することができ，この点では過塩素酸イオンと銀 $(\mathbf{I})$ の モル比は $1: 1$ である.

この滴定曲線において, 終点までの電導度の減少は三 元錯体の生成に伴い溶液中の過塩素酸イオン（当量電導 度 $\left.68 \mathrm{~S} \mathrm{~cm}^{2}\right)$ が，滴定剤, $\mathrm{Ag}(\mathrm{phen})_{2}{ }^{+}$の対イオンであ る酢酸イオン $\left(40.9 \mathrm{~S} \mathrm{~cm}^{2}\right)$ に置換されることによるもの であり, 終点以後の增大は過剩滴定剤中の $\mathrm{Ag}(\mathrm{phen})_{2}{ }^{+}$ と酢酸イオンとによる.

滴定剤の溶媒としては, ェタノールの外メタノール, アセトンについても検討したが，溶媒の相違による滴定 曲線の変化は認められなかったので, phen の溶媒とし て一般に用いられているェタノールを用いることとし た. その濃度を $(20 \sim 80) \%$ と変化させても終点の位置 に相違は認められないが，25\% 以下では滴定剤の調製

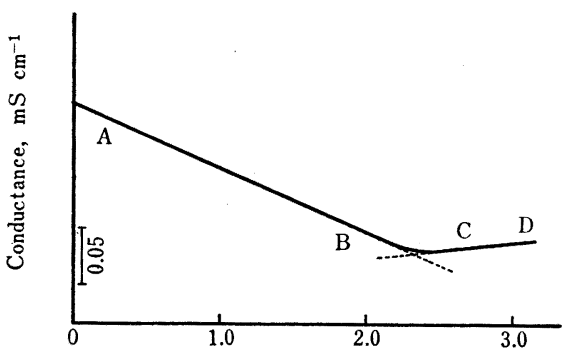

$0.1 \mathrm{M} \mathrm{Ag}$ (phen) ${ }_{2}+-40 \%$ ethanol, ml

Fig. 1 Typical conductometric titration curve of perchlorate ion

$\mathrm{ClO}_{4}^{-}: 22.65 \mathrm{mg}$; Acetate buffer solution; $\mathrm{pH} \mathrm{5.0;}$ Total volume : $100 \mathrm{ml}$; Titration speed : $0.20 \mathrm{ml} / \mathrm{min}$

が困難であること, 又 $60 \%$ 以上では直線の $\mathrm{AB}$ の領 域に湾曲が生ずる傾向にあることなどの難点があるの でエタノール濃度としては $40 \%$ とした。

\section{2 滴定剤中の phen/銀 (I) のモル比と pH の影響}

正確に phen $/ \mathrm{Ag}(\mathrm{I})=2.0$ となる滴定剂を調製するこ とは容易でない。滴定剤中に共存する過剩の phen 量の 影響を知る目的で，一定量の銀 (I) に対してモル比で少 過剩となるよう phenを添加した種々の溶液を調製し， 定量時の至適 $\mathrm{pH}$ との関係について調べた.

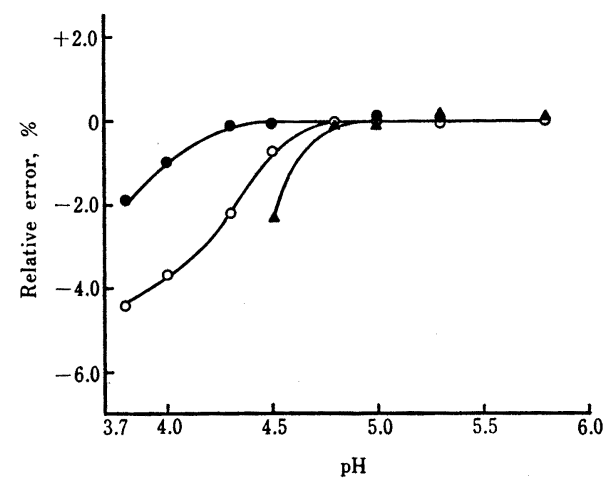

Fig. 2 Effect of pH

$\mathrm{ClO}_{4}^{-}: 22.65 \mathrm{mg}$; Acetate buffer solution; Total volume : $100 \mathrm{ml}$; Titration speed : $0.20 \mathrm{ml} / \mathrm{min}$; Molar ratio of phen/Ag(I) : - - 2.01, - -2.09 , $-\mathbf{\Delta}-2.36$

Fig. 2 に示した結果から, 滴定剤中の phen が過剩 となるに従って, 定量時の至適 $\mathrm{pH}$ 領域が狭くなる傾 向にある. しかし $\mathrm{pH}$ を 4.8 以上とすれば，モル比 が 2.01〜2.36 の範囲内ではいずれの滴定剤を用いても 
$0.2 \%$ 以下の 相対䛊差で過塩素酸イオンを定量するこ とが可能であった．本法では滴定時の $\mathrm{pH}$ を 5.0 と設 定した.

\section{3 緩衙溶液濃度と滴定時の液量の影響}

クェン酸塩, シュウ酸塩, 酒石酸塩は $\mathrm{Ag}(\mathrm{phen})_{2}{ }^{+}$ 錯体と難溶性の沈殿を形成するので，これらを緩衝溶夜 に用いることは好ましくない.Fig. 3，(A) は 3 の定量 操作に护酎酸塩緩衝溶液の濃度について検討した結 果である.

この結果から明らかなように，滴定時において 0.03 $\mathrm{M}$ 以上の濃度とすれば良好な結果が得られることが分 かるので，緩衝溶液濃度としては $0.06 \mathrm{M}$ とした。

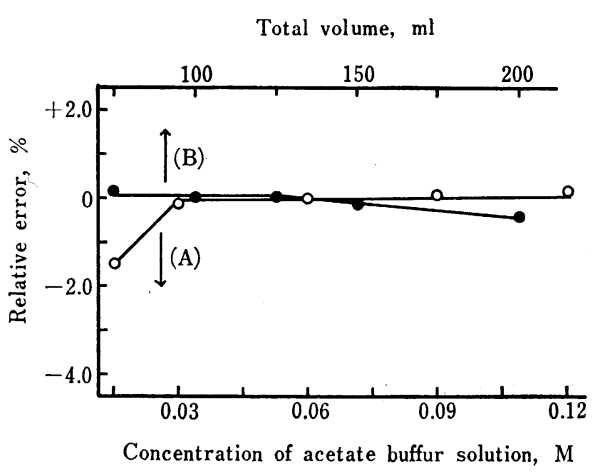

Fig. 3 Effects of concentration of buffer solution and total volume

$\mathrm{ClO}_{4}^{-}: 22.65 \mathrm{mg}$; Acetate buffer solution : $\mathrm{pH} 5.0$; Titration speed : $0.20 \mathrm{ml} / \mathrm{min}$; (A) $-\mathrm{O}-$ Constant volume, $100 \mathrm{ml}$; (B) $-0-$ Constant concentration, $0.06 \mathrm{M}$

滴定時の全液量については，液量の増加とともに相対 誤差が大きくなる傾向にあるので，(75～125) $\mathrm{ml}$ の範囲 に調節することが必要である \{Fig. 3, (B) \}.

\section{4 滴定速度の影響}

本法は沈殿生成反応であるため滴定速度は定量結果に 大きな影響を与える。

$22.65 \mathrm{mg}$ の過塩素酸イオンを採り, 3 定量操作に打 ける滴定速度を $(0.55 \sim 0.16) \mathrm{ml} / \mathrm{min}$ と変化させて滴 定速度の影響について検討した.

その結果, 滴定速度の增加とともに相対誤差が大きく なる傾向にあるが， $0.30 \mathrm{ml} / \mathrm{min}$ 以下とすれば $0.2 \%$ 以下の相対誤差で定量可能であった。

\section{5 金属イオン共存時の過塩素酸イオンの滴定曲線}

本法は， $\mathrm{Ag}(\mathrm{phen})_{2}{ }^{+}{ }^{+}$錯体を滴定剂に用いているた め, 試料中に phen と反応する金属イオンが共存すると 誤差を生じることが考えられる.

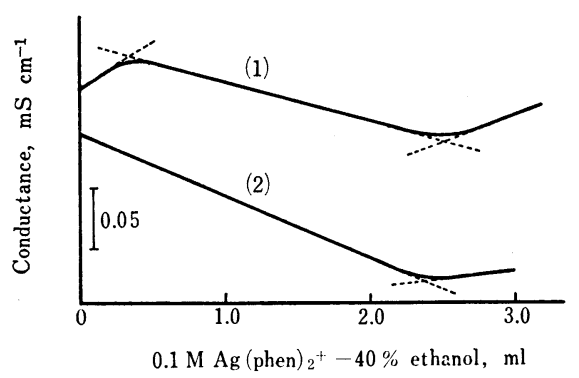

Fig. 4 Titration curves of perchlorate ion in the presence of diverse ion and masking agent $\mathrm{ClO}_{4}^{-}: 22.65 \mathrm{mg}$; Acetate buffer solution : $\mathrm{pH} 5.0$; Total volume : $100 \mathrm{ml}$; Titration speed $: 0.20 \mathrm{ml} / \mathrm{min}$; (1) $\mathrm{ClO}_{4}^{-}+\mathrm{Cu}(\mathrm{II}), 0.01 \mathrm{mmol}$; (2) (1) + phen

Fig. 4，（1）は金属イオンの 1 例として銅(II) が共存 したときのもので 2 個の屈折点が滴定曲線上に認められ る. 第 1 屈折点までは主として $\mathrm{Cu}(\mathrm{phen})_{2}{ }^{2+}$ 錯体の生 成に相当し，それ以後第 2 屈折点までは試料中の過塩素 酸イオン量に対応する.しかし，この滴定值には大きな 負誤差を生じた。

このような金属イオンの妨害を除去する目的で，あら かじめ phenを添加して金属イオンをマスキングしてし まら方法をとった。、マスキングに必要な phen 量は, 既 報11)準じ phen で滴定して求めることとした。

なお，この際の phen 量は, $0.8 \mathrm{mmol}$ までの過㮃量 は定量の妨害とはならない, 又, 溶媒のエタノール量も 最終 $3 \%$ までの共存は許容される.

Fig. 4，(2) は（1）と同一試料に打いて，銅(II)を phen 錯体としてマスキングした後のものであり，この ときには理論值と良く一致した定量結果となった。

\section{5 共存イオンの影響及び定量例}

(5.66〜 33.98) mg の過塩素酸イオンを含む試料溶液 を3 の定量操作に従って滴定した. Table 1 に示すよ らに，本法によれば $0.2 \%$ 以下の相対誤差と，0.9\% 以下の相対標準偏差で過塩素酸イオンを精度よく簡便に 定量することができる.

Table 2 に共存イオンについて検討した結果を示す. ここで共存イオンの闌 (molar ratio) には，22.65 mg の過塩素酸イオンに対して相対誤差を $\pm 0.5 \%$ 以内に 
Table 1 Determination of perchlorate ion

\begin{tabular}{rrrrr}
\hline $\begin{array}{c}\text { Taken } \\
(\mathrm{mg})\end{array}$ & $\begin{array}{c}\text { Found } \dagger \\
(\mathrm{mg})\end{array}$ & $\overbrace{(\mathrm{mg})}$ & $\begin{array}{c}\text { Errort } \\
(\%)\end{array}$ & $\begin{array}{c}\text { R.s. d. } \dagger \\
(\%)\end{array}$ \\
\hline 5.66 & 5.65 & -0.01 & -0.2 & 0.9 \\
11.33 & 11.30 & -0.03 & -0.2 & 0.2 \\
22.65 & 22.67 & +0.02 & +0.1 & 0.3 \\
33.98 & 33.97 & -0.01 & -0.03 & 0.2 \\
\hline
\end{tabular}

$\dagger$ Mean value of five determinations

Table 2 Effect of diverse ions $\left(\mathrm{ClO}_{4}^{-}\right.$ taken : $22.65 \mathrm{mg}$ )

\begin{tabular}{|c|c|c|c|c|c|}
\hline \multirow{2}{*}{ Ion } & \multirow{2}{*}{ Added as } & \multirow{2}{*}{$\begin{array}{l}\text { Ion/ClO } \mathrm{ClO}_{4}^{-} \\
\text {molar ratio }\end{array}$} & \multirow{2}{*}{$\begin{array}{l}\text { Found } \\
\text { (mg) }\end{array}$} & \multicolumn{2}{|c|}{ Error } \\
\hline & & & & (mg) & $(\%)$ \\
\hline None & & - & 22.67 & +0.02 & +0.1 \\
\hline $\mathrm{Ca}$ (II) & acetate & 5.0 & 22.61 & -0.04 & -0.2 \\
\hline $\operatorname{Mn}(\mathrm{II})$ & "I & 2.0 & 22.59 & -0.06 & -0.3 \\
\hline $\mathrm{Ni}(\mathrm{II}) \dagger$ & " & 1.0 & 22.61 & -0.04 & -0.2 \\
\hline $\mathrm{Co}(\mathrm{II}) \dagger$ & " & 1.0 & 22.71 & +0.06 & +0.3 \\
\hline $\mathrm{Zn}(\mathrm{II}) \dagger$ & "I & 1.0 & 22.54 & -0.11 & -0.5 \\
\hline $\mathrm{Cu}(\mathrm{II}) \dagger$ & " & 0.05 & 22.59 & -0.06 & -0.3 \\
\hline Cd(II) $†$ & " & 0.25 & 22.54 & -0.11 & -0.5 \\
\hline $\mathrm{NH}_{4}{ }^{+}$ & " & 5.0 & 22.71 & +0.06 & +0.3 \\
\hline $\mathrm{Cl}^{-}$ & sodium salt & 1.0 & 22.69 & +0.04 & +0.2 \\
\hline $\mathrm{F}^{-}$ & " & 10.0 & 22.69 & +0.04 & +0.2 \\
\hline $\mathrm{Br}^{-}$ & potassium salt & 0.01 & 22.77 & +0.12 & +0.5 \\
\hline $\mathrm{CN}^{-}$ & " & 0.05 & 22.75 & +0.10 & +0.4 \\
\hline $\mathrm{ClO}_{3}^{-}$ & " & 0.01 & 22.73 & +0.08 & +0.4 \\
\hline $\mathrm{BrO}_{3}^{-}$ & " & 0.25 & 22.67 & +0.02 & +0.1 \\
\hline $\mathrm{IO}_{3}^{-}$ & $"$ & 0.25 & 22.69 & +0.04 & +0.2 \\
\hline $\mathrm{SO}_{4}{ }^{2-}$ & sodium salt & 0.25 & 22.75 & +0.10 & +0.4 \\
\hline $\mathrm{PO}_{4}{ }^{3-}$ & $\begin{array}{l}\text { potassium salt } \\
\text { monohydrate }\end{array}$ & $\begin{array}{l}\mathrm{t} \\
\mathrm{te}\end{array}$ & 22.62 & -0.03 & -0.2 \\
\hline EDTA & disodium salt & 0.02 & 22.76 & +0.11 & +0.5 \\
\hline
\end{tabular}

$\dagger 0.2 \mathrm{M}$ phen- $40 \%$ ethanol-water solution added

とどめておくことが可能な共存許容量を示した.

金属イオンについては，3に示した操作によりあらか じめ phenを添加し，これら金属イオンをマスキングす ることで, ニッケル(II), コバルト(II), 亜鉛 $(\mathrm{II})$ など では等モル量まで, 銅 $(\mathrm{II})$, カドミウム(II) についても 示された量までの共存は妨害とならない, 又 $\mathrm{NH}_{4}{ }^{+}$あ 5 倍モル量の共存は可能である. 塩化物イオンについ ては等モル量の共存は許される. その他の陰イオンは $\mathrm{Ag}$ (phen) $)_{2}+$ 錯体と反応するものが多く, Table 2 に 示した値以上の共存は好ましくない. 更に, $\mathrm{NO}_{3}{ }^{-}, \mathrm{I}^{-}$, $\mathrm{SCN}-, \mathrm{IO}_{4}{ }^{-}, \mathrm{S}_{2} \mathrm{O}_{3}{ }^{2-}$ などの共存は許されない.

\section{6 忘用 例}

本法を試薬級の過塩素酸アンモニウムの純度検定に適 用した. 又, 同一試料を塩化テトラフェニルアルソニウ ムを用いる Baczuk ら7) の方法により分析した結果を 合わせて示す (Table 3).
Table 3 Determination of purity for ammonium perchlorate (reagent grade)

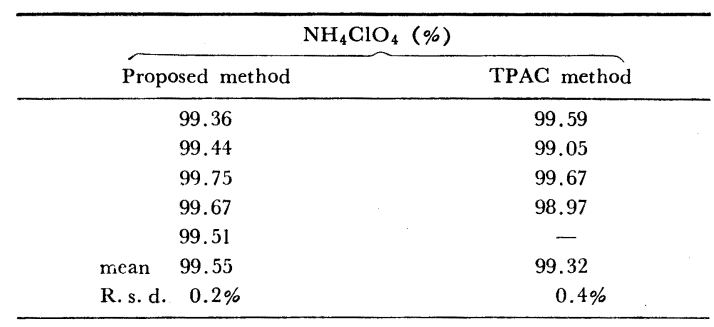

TPAC : Tetraphenylarsonium chloride

Table 3 から明らかなよらに，本法は Baczuk らの 方法で得た結果と良い一致が見られる. 本法は試薬が安 価な点や操作の簡便性及び精度の点で十分実用に供しう る方法であろう。

\section{7 生成した三元錯体の検討}

\section{$7 \cdot 1$ 三元錯体の組成比}

銀(I) 及び phen が過塩素酸イオンと反応して生成す る三元錯体の組成比を連続変化法により検討した.

Fig. 5 は過塩素酸イオンと phen との溶存量の和を $0.6 \mathrm{mmol}$ 一定とした試料溶液の $\mathrm{pH}$ を酢酸塩緩衝溶 液を用いて 5.0 とした後， $0.20 \mathrm{ml} / \mathrm{min}$ の速度で銀 (I) 標準溶液により滴定し，その際の屈折点をプロット したものである。なお，用いた 銀 $(\mathbf{I})$ 標準溶液の力価 は, 塩化ナトリウム標準溶液を用いる常法により決定し た.

この結果から, [phen $] /\left[\mathrm{ClO}_{4}^{-}\right]=2$ であることが分

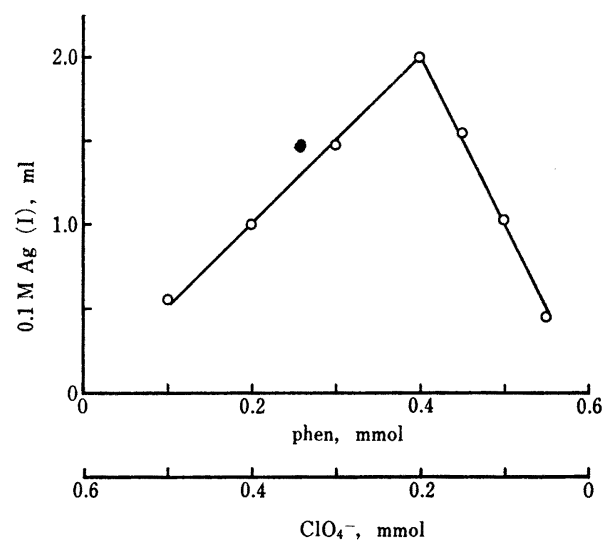

Fig. 5 Continuous variation method for Ag-phen$\mathrm{ClO}_{4}$ ternary complex

Acetate buffer solution : $\mathrm{pH} 5.0$; Total volume : 100 $\mathrm{ml}$; Titration speed : $0.20 \mathrm{ml} / \mathrm{min}$ 
かる. 更に [phen]/[ $\left.\mathrm{ClO}_{4}^{-}\right]=2$ における $[\mathrm{Ag}(\mathrm{I})] /$ $\left[\mathrm{ClO}_{4}^{-}\right.$する三元錯体の組成はモル比で銀 (I) : phen : $\mathrm{ClO}_{4}^{-}=$ 1:2:1 であると考えられる.モル比法による結果もこ れと同様な組成比を持つことを示していた.

\section{2 三元錯体， $\mathrm{Ag}$ (phen) ${ }_{2} \mathrm{ClO}_{4}$ の見掛けの浴解度 㮴の検討}

生成する三元錯体の見掛けの溶解度積を原子吸光法に より検討した。

$22.65 \mathrm{mg}$ の過塩素酸イオンを 3 の定量操作に従って 滴定し，生成した沈殿を沪過し洗浄した後，滴定時と同 一の $\mathrm{pH}$ 及び緩衝溶液濃度とした水溶液 $100 \mathrm{ml}$ に懸 濁させ，時々振とうしながら約 10 時間恒温そう中に放 置する. その後懸濁液の適当量を分取して沪過し，沪 液中の 銀 $(\mathbf{I})$ を原子吸光法により求める. 又, 過塩素 酸イオンと同様に硝酸イオンむ $\mathrm{Ag}(\mathrm{phen})_{2}{ }^{+}$錯体と 反応することが知られて括り ${ }^{16)}$ ，生成する三元錯体， $\mathrm{Ag}$ (phen) ${ }_{2} \mathrm{NO}_{3}$ についても同様な操作により検討した。 このとき $25^{\circ} \mathrm{C}$ に执いて $\mathrm{Ag}(\mathrm{phen})_{2} \mathrm{ClO}_{4}$ では 4 時間 で, $\mathrm{Ag}(\mathrm{phen}){ }_{2} \mathrm{NO}_{3}$ では 2 時間で各々溶解平衡に達し た.

Table 4 Apparent solubility products of precipitates

\begin{tabular}{|c|c|c|c|}
\hline \multirow{2}{*}{ Temp. $\left({ }^{\circ} \mathrm{C}\right)$} & \multicolumn{2}{|c|}{$\log K_{\text {sp }}{ }^{\prime}$} & \\
\hline & $\mathrm{Ag}(\text { phen })_{2} \mathrm{ClO}_{4}$ & $\mathrm{Ag}$ (phen) ${ }_{2} \mathrm{NO}$ & \\
\hline 25 & -24.25 & -18.60 & $-18.95^{15}$ \\
\hline 35 & -22.60 & -17.56 & \\
\hline 45 & -22.14 & -17.40 & \\
\hline 55 & -21.73 & -15.66 & \\
\hline$\Delta \mathrm{H}(\mathrm{kcal} / \mathrm{mol})$ & 36.7 & 41.1 & \\
\hline
\end{tabular}

Acetate buffer solution : $\mathrm{pH} 5.0$

得られた銀 $(\mathrm{I})$ 濃度と生成する三元錯体の組成比を用 いて計算された $(25 \sim 55){ }^{\circ} \mathbf{C}$ の範囲における見掛けの溶 解度積を Table 4 亿示す. $\mathrm{Ag}$ (phen) ${ }_{2} \mathrm{NO}_{3}$ では Scharff ら16)の值と良く一致した結果となっている. Ag(phen) $\mathrm{ClO}_{4}$ ではその值が $\log K_{\mathrm{sp}}{ }^{\prime}=-24.25$ となり更に難溶 性の三元錯体が形成されていることが分かる．又，これ らの值から三元錯体が生成する際の反応熱は $\mathrm{Ag}(\text { phen })_{2}$ $\mathrm{ClO}_{4}$ では $36.7 \mathrm{kcal}, \mathrm{Ag}(\mathrm{phen}){ }_{2} \mathrm{NO}_{3}$ では $41.1 \mathrm{kcal}$ と算出され，これらの生成反応が吸熱反応であることが 分かる.

(1979 年 10 月, 日本分析化学会) 第 28 年会において一部発表

\section{文献}

1) N. L. Coump, N. C. Johnson : Anal. Chem., 27, 1007 (1955) .

2) A. de Sousa : Chemist-Analyst, 49, 18 (1960) .

3) A. de Sousa : Anal. Chim. Acta, 24, 424 (1961).

4) E. Kruz, G. Kober, M. Berl : Anal. Chem., 30, 1983 (1958).

5) G. P. Haight, Jr. : Anal. Chem., 25, 642(1953) .

6) E. A. Burns, R. F. Muraca : Anal. Chem., 32, 1316 (1960).

7) R. J. Baczuk, W. T. Bolleter : Anal. Chem., 39, 93 (1967).

8) R. J. Baczuk, R. J. DuBois : Anal. Chem., 40, 685 (1968).

9）根津弘幸：分化，10，571 (1961).

10) 山本勇麓：分化，21，418 (1972).

11）吉田仁志, 林田一良, 多賀光彦, 蟇目清一郎 : 分 化, 26, 461 (1977).

12）吉田仁志，水野和訓，多賀光彦，基目清一郎：分 化, 25, 12 (1976).

13）林田一良，吉田仁志，多賀光彦，㱳目清一郎：分 化, 28, 748 (1979)

14) P. O. Bethge : Anal. Chim. Acta, 10, 310 (1954) .

15）大久保悌二，青木交雄，寺岡藤一：日化，89, 432 (1968).

16) J. P. Scharff, M. R. Paris : Bull. Soc. Chim. Fr., 1967, 1782.

$$
\text { 家 }
$$

Conductometric titration of perchlorate ion by the formation of silver-1,10-phenanthrolineperchlorate ternary complex. Ichiro HAYASHIDA, Hitoshi Yoshida, Mitsuhiko TAga and Seiichiro Hikime (Department of Chemistry, Faculty of Science, Hokkaido University, Nishi-8, Kita-10, Sapporo-shi, Hokkaido)

Perchlorate ion forms insoluble ternary complex, $\left.[\mathrm{Ag} \text { (phen) })_{2} \mathrm{ClO}_{4}\right]$, with $\mathrm{Ag}(\mathrm{I})$ in the presence of 1,10-phenanthroline(phen). Simple and direct determination of perchlorate ion based on the formation of this ternary complex was investigated by conductometric titration. Recommended procedure is as follows; An aliquot of sample solution containing (6 $34) \mathrm{mg}$ of perchlorate ion is transferred into a $100 \mathrm{ml}$ beaker. Two $\mathrm{ml}$ of $3 \mathrm{M}$ acetate buffer solution is added to it and $\mathrm{pH}$ is adjusted to 5.0. The sample solution is diluted to a volume of $100 \mathrm{ml}$ and titrated with $0.1 \mathrm{M} \mathrm{Ag}$ (phen) ${ }_{2}^{+}$complex standard solution (40\% ethanol-water solution) at the rate of $0.20 \mathrm{ml}$ / min. The change of phen concentration up to 2.36 on the molar ratio of phen $/ \mathrm{Ag}(\mathrm{I})$ in the standard solution had no interference with the determination of perchlorate ion at $\mathrm{pH} 4.8 \sim 5.8$ (Fig. 2). When citrate, tartrate or oxalate buffer solution was used in place of acetate buffer solution, the large positive error was obtained. By this method, the determination of perchlorate ion was performed satisfactorily with relative standard deviation of less than $0.9 \%$ (Table 1). The effect of diverse ions on the determination 
was studied in detail (Table 2). The comparison of this method with tetraphenylarsonium chloride technique on the determination of purity for ammonium perchlorate was also investigated (Table 3). The obtained value of apparent solubility product $\left(\log K_{\mathrm{sp}}{ }^{\prime}\right)$ of this ternary complex was -24.25 and the heat of reaction which was calculated from this value was $36.7 \mathrm{kcal} / \mathrm{mol}$ (Table 4 ).

(Received Nov. 5, 1979)

\section{Keywords}

$\operatorname{Ag}(1,10 \text {-phenanthroline })_{2}{ }^{+}$titrant

Conductometric titration

Perchlorate ion

Ternary complex

\title{
ランタンを用いるスズの黒鉛炉原子吸光分析法
}

\author{
斉 加実彦®，池田 友成* \\ (1979 年 8 月 9 日受理)
}

\begin{abstract}
微量スズの黒鉛炉による電気加熱原子化原子吸光分析法について，原子化条件を定めた後，試料の液 性について検討して条件を定めた。共存成分の影響については 12 種の金属イオンなどについて実験し， 妨害成分のアルミニウム，アンチモン，テルル，ヒ素や酒石酸などは硝酸ランタンを添加することによ り影響を防止できた．ランタンはスズの尔量に増感効果を示し，又アンモニア性に抢いてスズを共沈さ せるのでこれを分離法として用い，亜鉛地金などのスズの定量に適用した。
\end{abstract}

\section{1 緒馬}

電気加熱原子化原子吸光分析法はフレーム原子化法に 比較して試料所要量が少量で, 感度が高いことなどの特 徵があり1) 3)，原子化には黒鉛管が一般に利用されてい る.

本実験では分析上比較的やっかい視されている微量ス ズの定量法を取り上げることとした．黑鉛管法によるス ズの定量法は鉄試料を対象としたものなど4)5) があり， 又近年，同時に 4 報告が討論会でなされている6) 99).

本実験では，スズ試料溶液の液性と原子化条件の検 討，共存成分の影響とその対策について検討し，ランタ ンを緩衝剤として用いることとした. ランタンはアンモ ニア性溶液でスズを共沈させるので，スズの捕集分離方 法としても用いた．この方法を亜鉛地金及び銅地金中の スズの定量に応用して，その結果を発光分光分析法など と比較した.

\section{2 装置及び試薬}

\section{1 装}

原子吸光分光分析装置 : 日本ジャーレル・アッシ二社

* 東洋大学工学部：埼玉県川越市鲸井中野台 2100
製 AA-781

フレームレスアトマイザー：日本ジャーレル・アッシ 工社製 FLA-10

光源：浜松テレビ社製 L 233 型スズ中空陰極ランプ バックグラウンド測定用光源：高輝度重水素ランプ マイクロピペット：ギルソン社製ピペットマン P 200 黒鉛管：日本ジャーレル・アッシュ社製のものを用い た。

\section{2 試 薬}

試薬類は試薬特級品を用い，アルゴンはアルゴン 99.9 $\%$ 以上のものを用いた。

硝酸性スズ標準液：金属スズ $(99.99 \%) 0.500 \mathrm{~g}$ を $(1+1)$ 塩酸 $50 \mathrm{ml}$ と硝酸 $10 \mathrm{ml}$ で加熱溶解し, 放冷 後硝酸 $26 \mathrm{ml}$ と水を追加し全量を $500 \mathrm{ml}$ として, ス ズ $1 \mathrm{mg} / \mathrm{ml}$ の溶液を調製する.この原液から使用の都 度スズ $0.2 \mu \mathrm{g} / \mathrm{ml}$ を含む $1 \mathrm{~N}$ 硝酸溶液を調製して用い た。

塩酸性スズ標準液：金属スズ $(99.99 \%)$ を塩酸に溶 解し, 水でうすめてスズ $1 \mathrm{mg} / \mathrm{ml}$ の溶液を調製し, こ の原液から使用の都度スズ $0.5 \mu \mathrm{g} / \mathrm{ml}$ を含む $1 \mathrm{~N}$ 塩酸 溶液を調製して用いた。

ランタン溶液：硝酸ランタン $12.5 \mathrm{~g}$ を硝酸 $(1+13)$ に溶解して $200 \mathrm{ml}$ とし, ランタン $20 \mathrm{mg} / \mathrm{ml}$ 溶液を調 製した。

その他の標準液の調製 